\title{
IMPACTS OF LOGGING ON AUTUMN BIRD POPULATIONS IN THE SOUTHERN FORESTS OF TASMANIA
}

\author{
by Andrew B. Hingston
}

(with four tables, one text-figure and two appendices)

Hingston, A.B., 2000 (31:xii): Impacts of logging on autumn bird populations in the southern forests of Tasmania. Pap. Proc. R. Soc. Tasm. 134: 19-28. ISSN 0080-4703. Geography and Environmental Studies, University of Tasmania, GPO Box 252-78, Hobart, Tasmania, Australia 7001.

Bird assemblages were documented in different forest types in the Warra Long Term Ecological Research Site in Tasmania's southern forests. Sampling was undertaken in areas immediately after clearfelling and burning, in regrowth up to 26 years after this treatment, in selectively logged forest, in regrowth following wildfire, and in old-growth forest. It was found that areas subjected to clearfelling and burning supported assemblages which were distinct from areas with other histories, in that they comprised fewer species and individuals. This adverse impact of silvicultural practices on bird populations was apparent in all strata of the forest; canopy, mid-layer and ground. Immediately after clearfelling and burning, coupes were colonised by ground-feeding insectivores more typical of open country than of the surrounding wet sclerophyll forests, but these were quickly displaced with the advent of young regrowth, which was gradually colonised by forest-inhabiting species. However, these assemblages were still depauperate as much as 26 years after clearfelling. Comparisons with previous studies suggest that this deleterious impact of forestry operations on birds may be ameliorated by the retention of patches in logging coupes. This is supported by the absence of significant impacts on birds in parts of the area which were selectively logged 25 years earlier. Key Words: silviculture, forestry, fire, regrowth, Tasmania

\section{INTRODUCTION}

Previous studies have found dramatic decreases in bird populations following clearfelling of eucalypt forests in Tasmania (Green 1977, Coulson \& Coulson 1980, Dickinson et al. 1986, Taylor et al. 1997) and other parts of Australia (Loyn 1980, Smith 1984, Kavanagh et al. 1985, Recher et al. 1985, Smith 1985b). However, some species of birds more typical of open country may increase in abundance after clearfelling (Green 1977, Loyn 1980, 1985, Kavanagh et al. 1985, Dickinson et al. 1986), but such species are rapidly excluded in regenerating vegetation (Kavanagh et al. 1985, Loyn 1985) as the original bird communities reestablish (Coulson \& Coulson 1980, Smith 1984, Kavanagh et al. 1985). Those inhabiting undergrowth are particularly adept at recolonisation of dense young regrowth (Loyn 1985, Smith 1985a, b). As the regrowth develops, other species return, with bird communities in regrowth wet sclerophyll forests $30-40$ years after logging sometimes being fairly similar to those in mature forests. However, several species were still less common in regrowth forest of this age than in mature forest in Victoria (Loyn 1985).

The impact of forestry operations on bird populations may be lessened in Tasmanian dry sclerophyll forests by retaining trees in logged coupes (Taylor \& Haseler 1995, Taylor et al. 1997). In Western Australian eucalypt forest, selective logging, which removed less than two-thirds of the existing canopy, had little effect on bird populations (Abbott \& van Huerck 1985).

The research described here aimed to quantify the effects on birds of the standard silvicultural treatment for wet forests (clearfelling followed by high intensity burning) in the Warra Long Term Ecological Research Site in Tasmania's southern forests. In particular, the capacity for birds to recolonise logged coupes was examined by comparing populations in different ages of silvicultural regeneration. The impact of the standard treatment was also compared to the effects of selective logging and wildfire.

\section{METHODS}

Birds were surveyed, between 7 April and 28 May 1998, in coupes of varying ages and silvicultural treatments in Tasmania's southern forests, along Warra Road and South Weld Road. Thirty-three sites, all centred $50 \mathrm{~m}$ from the road edge, were categorised into three different treatments according to their silvicultural histories and current vegetation. These were defined as: old-growth (sites $\mathrm{O} 1$ to O13); regrowth (sites R1 to R5), encompassing forests which were selectively logged approximately 25 years ago without being subjected to high intensity regeneration burns, and regrowth forests resulting from wildfire; and silvicultural regeneration (sites $S 1$ to $S 15$ ), which included all areas subject to clearfelling followed by a high intensity regeneration burn between zero and 26 years ago. Sites representing the different treatments were scattered thoughout the survey area as much as possible in order to minimise any local geographic variation in bird assemblages since this, if present, would have confounded the results.

\section{Forest Types and Silvicultural History}

The study area was dominated by Eucalyptus obliqua L'Herit wet sclerophyll forest. However, a xeric to mesic vegetation gradient was apparent. The most xeric areas carried E. nitida Hook. f. over a dense sclerophyllous scrub. This graded into low E. obliqua forest with a sclerophyllous understorey, then into taller $E$. obliqua with a broad-leaved understorey. In the more mesic sites $E$. regnans $\mathrm{F}$. Muell. or $E$. delegatensis $\mathrm{R}$. T. Baker sometimes grew alongside E. obliqua, and the wettest sites supported mixed forest.

Most of the old-growth sites (sites O1 to O13, numbered from most xeric to most mesic) were last burnt in 1934 , although the three most mesic sites had not been burnt since 1898. All of the regrowth forests (sites R1 to R5, numbered from most xeric to most mesic) were burnt in 
1934; the difference between these sites and old-growth burnt at the same time apparently due to different fire intensities. Two of these sites, R2 and R3, were also logged in the early 1970 s for pulpwood and sawlogs with seed trees retained. Attempts to burn these sites in 1973 failed, but they were burnt in 1977, when a regeneration burn in a nearby clearfelled coupe escaped. Silvicultural regeneration sites ( $S 1$ to $\$ 15$, numbered from youngest to oldest) were divided into two categories according to age. Young silvicultural regeneration included one recently burnt coupe (S1) and four sites (S2-S5)which had been logged between four and six years earlier and carried dense eucalypts $2-5 \mathrm{~m}$ in height. Older silvicultural regeneration ranged in age from nine years (S6) to 26 years in age, with eucalypts $6-20 \mathrm{~m}$ in height.

It was assumed that the impacts of the three treatments were not confounded by differences in original vegetation types and, hence, bird assemblages. This assumption appeared valid, as the range of plant species appeared reasonably uniform across the three treatments, and both old-growth and regrowth encompassed similar ranges in canopy heights. E. obliqua was the most common overstorey tree in most old-growth sites, ranging in height from $30-70 \mathrm{~m}$. Sites $\mathrm{O} 7$ and $\mathrm{O} 8$ also carried some E. regnans, and $E$. delegatensis was also present on site O11. However, $O 1$ differed by carrying $E$. nitida $10 \mathrm{~m}$ in height instead of E. obliqua. All regrowth forest sites were also dominated by E. obliqua, with E. regnans also occurring at R5. Sites R2 and R3 carried remnant trees $70 \mathrm{~m}$ in height over $15-20 \mathrm{~m}$ high regrowth, while R1, R4 and R5 were mostly evenaged trees of $30-40 \mathrm{~m}$. Understoreys in both old-growth and regrowth ranged from sclerophyllous through broadleaved to rainforest. Silvicultural regeneration was also dominated by $E$. obliqua, with $E$. regnans and $E$. delegatensis also sown on $\$ 2, S 4, S 6$ and $S 7$. Where understoreys were beginning to develop after silvicultural regeneration. these comprised a similar range of plants to those in other sites.

\section{Survey Technique}

Spot surveys of 15 minutes duration were conducted at each site on fine days with little wind or rain. The daylight hours were divided into five periods of two hours each, with each site being surveyed for birds three times in each period to remove any confounding temporal effects on bird activity. All birds seen or heard within approximately $200 \mathrm{~m}$ were noted, with care being taken to exclude birds calling from different vegetation nearby. Birds observed flying over the survey sites well above the height of the vegetation and, therefore, not interacting with it, were excluded from the analysis. However, raptors which flew over the sites were included, as this is their mode of foraging. Golden and olive whistlers were combined in the data analysis, due to difficulties differentiating some of their calls. It was assumed that birds were equally easy to detect in each habitat, and that bird assemblages in areas subjected to the different treatments were independent of each other.

\section{Data Analysis}

For each site, the numbers of each bird species recorded were totalled for the 15 surveys. These sites were ordinated using semi-strong hybrid multidimensional scaling (ssh mds) according to their bird assemblages, using the computer programme PATN (Belbin 1993). The bird species which were significant predictors $(\mathrm{p}<0.05)$ of the variation between communities at these sites were fitted to the ordination plot as vectors.

Differences in bird assemblages between the three treatments were analysed, using One-way Analysis of Variance (ANOVA) when the data were normally distributed and the non-parametric Kruskal-Wallis Test whenever this assumption was not met. If significant differences between treatments were apparent, pairwise comparisons were then conducted between treatments, using Student-Newman-Keuls Test for normally distributed data and Dunn's Method for non-normal data. The total numbers of individual birds (normal data) and species (non-normal data, $\mathrm{p}=0.0249$ ) observed at each site during the 15 surveys were analysed in this way. As there appeared to be a major disjunction in the total numbers of species between young ( $0-6$ years old) and older ( $9-26$ years old) silvicultural regeneration (appendix 1), subsequent tests were used to investigate differences in species richness (normal data) and the numbers of individuals (non-normal data, $\mathrm{p}=0.0239$ ) between these two treatments, regrowth and old-growth.

The same statistical technique was used to investigate the differences between the three treatments in the total numbers of individuals of each bird species observed at each site during 15 surveys. The total numbers of birds in each foraging guild observed at each site was also investigated in this way. Guild allocations were based on the height at which most foraging was undertaken, and were the same as those used by Taylor \& Haseler (1995) and Taylor et al. (1997), except for the brown goshawk and green rosella, which were classed as canopy-feeders here. Hence, the guild allocations were:

(1) canopy:

spotted pardalote Pardalotus punctatus striated pardalote $P$. striatus

black-headed honeyeater Melithreptus affinis strong-billed honeyeater $M$. validirostris yellow wattlebird Anthochaera paradoxa black-faced cuckoo-shrike Coracina novaehollandiae green rosella Platycercus caledonicus sulphur-crested cockatoo Cacatua galerita brown goshawk Accipiter fasciatus

(2) mid-layer:

grey fantail Rhipidura fuliginosa

brown thornbill Acanthiza pusilla

Tasmanian thornbill $A$. ewingii

scrubtit Acanthornis magnus

silvereye Zosterops lateralis

eastern spinebill Acanthorhynchus tenuirostris

crescent honeyeater Phylidonyris pyrrhoptera

New Holland honeyeater $P$. novaehollandiae

yellow-throated honeyeater Lichenostomus flavicollis

golden whistler Pachycephala pectoralis

olive whistler $P$. olivacea

grey shrike-thrush Colluricincla harmonica

yellow-tailed black cockatoo Calyptorhynchus funereus

(3) ground:

beautiful firetail Stagonopleura bella

flame robin Petroica phoenicea 
pink robin $P$. rodinogaster

scarlet robin $P$. multicolor

dusky robin Melanodryas vittata

superb fairy-wren Malurus cyaneus

Tasmanian scrubwren Sericornis humilis

Bassian thrush Zoothera lunulata

superb lyrebird Menura novaehollandiae

grey butcherbird Cracticus torquatus

black currawong Strepera fuliginosa

forest raven Corvus tasmanicus

wedge-tailed eagle Aquila audax.

For those species and guilds which exhibited significant pairwise differences between abundances in silvicultural regrowth and in other forest types, subsequent analyses were conducted, whereby only silvicultural regrowth greater than nine years old was included.

\section{RESULTS}

There were significant differences between forest treatments in the total numbers of individuals $(\mathrm{p}<0.0001)$ and species $(\mathrm{p}<0.01)$ of birds observed during 15 surveys. Pairwise tests demonstrated that there were significantly fewer individuals and species in silvicultural regeneration than in either of the other two treatments (table 1A, B). Fewer individuals were observed at each silvicultural regeneration site than at any of the other sites (appendices 1,2). Hence, bird assemblages in silvicultural regeneration were distinct from all others and negatively associated with abundances of most bird species (fig. 1). This difference did not appear to be completely due to lower canopy heights in silvicultural regeneration, because the bird assemblage at site $\mathrm{O} 1$, with a canopy only $10 \mathrm{~m}$ high, was more similar to that in other old-growth forests than in silvicultural regeneration (fig. 1).

In contrast no significant differences were recorded in the numbers of individuals (table 1A) or species (table 1B) between regrowth forests, resulting from wildfire or selective logging without intense regeneration burning, and oldgrowth forests. Furthermore, there was substantial overlap in the compositions of bird assemblages in regrowth and old-growth forests, with most bird species being strongly associated with these treatments (fig. 1). Within both regrowth and old-growth forests there were parallel changes in bird communities from mesic to xeric vegetation types (fig. 1A). Wetter forests were typified by the scrubtit, black currawong, pink robin and grey fantail. In contrast, the beautiful firetail, crescent honeyeater and silvereye were characteristic of drier forests (fig. 1).

Of the areas subjected to the standard silvicultural regeneration regime (clearfelling followed by intense burning of logging slash) the site which had just been burnt (S1) was most distinct in its bird assemblage from those in oldgrowth and regrowth forests (fig. 1A). This bird assemblage was very different to all others, with 24 of the 28 dusky robins, seven of the nine scarlet robins, and three of the 11 flame robins recorded in the whole survey being from this site (appendices 1,2). The only other birds observed at this site were eight forest ravens, three superb fairy-wrens and one Tasmanian scrubwren (appendix 1).

This difference in bird assemblages, between areas which were clearfelled and burnt and those which were not, gradually declined as silvicultural regrowth aged (fig. 1A).
This can be attributed to the significantly fewer species in regeneration aged less than six years compared with that aged between nine and 26 years (table $1 \mathrm{C}$ ). However, this older age class of silvicultural regeneration was still significantly less species-rich than both old-growth and regrowth forests (table $1 \mathrm{C}$ ). Numbers of individual birds recorded from older silvicultural regeneration were also significantly lower than from old-growth forests (table 1D).

All bird species which exhibited significant differences in abundance between treatments were less common in silvicultural regeneration than in either old-growth or regrowth forests (table 2). Of the 14 species, ten were significantly less common in silvicultural regeneration than in old-growth forests, and seven were significantly less common in silvicultural regeneration than in regrowth forests resulting from wildfire or selective logging. However, none showed significant differences in abundance between old-growth and regrowth forests (table 2). The differences found cannot be attributed to the inclusion of very young regrowth in the silvicultural regeneration treatment, as all 11 species which were significantly less common in silvicultural regeneration than in old-growth and/or regrowth forests were still less common in older silvicultural regeneration than in either of the other two treatments (table 3). Of these species, seven were significantly less common in older silvicultural regeneration than in oldgrowth forests and five were significantly less common in older silvicultural regeneration than in regrowth forests (table 3). The birds most severely affected by standard silvicultural practices were the green rosella, grey shrikethrush, spotted pardalote, Tasmanian scrubwren, yellowthroated honeyeater, silvereye and the whistlers (table 3 ).

The impact of standard silvicultural practices on bird species abundances was evident in all strata of the forest (tables 2,3). Total numbers of individuals in each guild were always lower in silvicultural regeneration than either old-growth or regrowth forests (table 2). This difference was significant between silvicultural regeneration and oldgrowth forests in all three guilds. Birds which fed in the canopy or mid-layer were also significantly less common in silvicultural regeneration than in regrowth forests resulting from wildfire or selective logging without high intensity burning. However, the lower number of ground-feeding birds in silvicultural regeneration than in regrowth forests was not significant. In contrast to the marked differences between silvicultural regeneration and other treatments, there were no significant differences between old-growth and regrowth forests in abundances of birds in any of the guilds (table 2). The differences found cannot be attributed to the inclusion of very young regrowth in the silvicultural regeneration treatment, as exactly the same patterns were apparent when young silvicultural regeneration was excluded from the analysis (table 3).

Only four species which averaged more than two individuals per 15 surveys per site in any given treatment did not exhibit significant differences in abundances between treatments. These were the black currawong, superb fairywren, strong-billed honeyeater and yellow-tailed black cockatoo (table 2). Abundances of all these species were characterised by standard deviations greater than their means in at least one treatment, and only one (superb fairy-wren) was more common in silvicultural regeneration than in either old-growth or regrowth forests (table 2). 

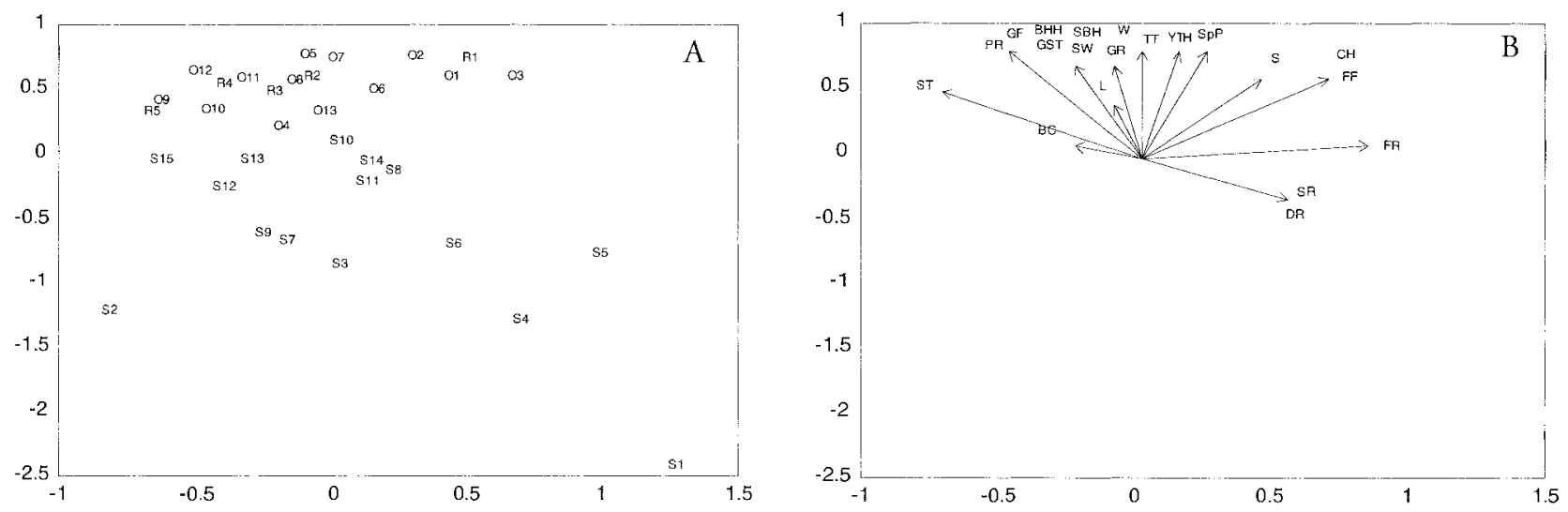

FIG. 1 -Relationships between spot survey sites in bird community compositions over 15 surveys. Axes for $(A)$ and $(B)$ correspond for ease of comparison. Stress for 3 axes $=0.129$. (A) Ordination of survey sites. (B) Bird species which were significant predictors of the variation between sites futted as vectors. Species codes are given in table 2.

TABLE 1

Pairwise comparisons based on observations during 15 syrveys at each site*

(A) Total number of individual birds using StudentNewman-Keuls Test

$\begin{array}{lccc}\text { Comparison } & \text { Means } & \mathrm{q} & \mathrm{P} \\ & & & \\ \text { Ov. S } & 252.6 \text { v. } 90.6 & 12.22 & <0.05 \\ \text { Ov. R } & 252.6 \text { v. } 246.8 & 0.316 & \text { N.S. } \\ \text { Rv. S } & 246.8 \text { v. } 90.6 & 8.644 & <0.05\end{array}$

(C) Total number of bird species using StudentNewman-Keuls Test

$\begin{array}{lccc}\text { Comparison } & \text { Means } & \mathrm{q} & \mathrm{p} \\ \text { 0-6 y v. 9-26y } & 7.20 \text { v. } 17.30 & 16.97 & <0.05 \\ \text { Ov. 0-6y } & 19.31 \text { v. } 7.20 & 21.18 & <0.05 \\ \text { R v. 0-6y } & 19.20 \text { v. } 7.20 & 17.46 & <0.05 \\ \text { Ov. 9-26 y } & 19.31 \text { v. } 17.30 & 4.393 & <0.05 \\ \text { R v. 9-26y } & 19.20 \text { v. } 17.30 & 3.193 & <0.05\end{array}$

* $\mathrm{O}=$ old-growth, $\mathrm{R}$ = regrowth, $\mathrm{S}=$ silviculture

\section{DISCUSSION}

\section{Impacts of Clearfelling on Bird Communities}

The depauperate bird assemblages following clearfelling and high intensity burning in Tasmania's southern forests accord with previous studies elsewhere (e.g. Green 1977 , Coulson \& Coulson 1980, Smith 1984, 1985b, Kavanagh et al. 1985, Recher et al. 1985, Dickinson et al. 1986). This adverse impact of standard silvicultural practices on bird abundances was consistent across all strata of the forest, in contrast to the highly variable results of Taylor \& Haseler (1995) in Tasmanian dry sclerophyll forests.

Low numbers of individuals and species of birds in silvicultural regeneration can be attributed to certain components of the vegetation. In a study of 11 eucalypt forest types and one heathland in Victoria and Queensland
(B) Total number of bird species using Dunn's Method

Comparison Medians $\quad \mathrm{Q} \quad \mathrm{p}$

$\begin{array}{llll}\text { Ov. S } & 19.0 \text { v. } 16.0 & 2.507 & <0.05 \\ \text { Ov. R } & 19.0 \text { v. } 19.0 & 0.005 & \text { N.S. } \\ \text { Rv. S } & 19.0 \text { v. } 16.0 & 3.410 & <0.05\end{array}$

(D) Total number of individual birds using Dunn's Method

\begin{tabular}{lccc} 
Comparison & Medians & $\mathrm{Q}$ & $\mathrm{P}$ \\
0-6 y v. 9-26y & 38.0 v. 112.0 & 1.360 & $\mathrm{NS}$ \\
O v. 0-6 y & 245.0 v. 38.0 & 4.269 & $<0.05$ \\
R v. 0-6 y & 236.0 v. 38.0 & 3.303 & $<0.05$ \\
O v. 9-26 y & 245.0 v. 112.0 & 3.571 & $<0.05$ \\
R v. 9-26 y & 236.0 v. 112.0 & 2.455 & $\mathrm{NS}$ \\
\hline
\end{tabular}

(Gilmore 1985), positive correlations were found between densities of insectivorous birds and both plant biomass and canopy height. However, the low numbers of birds in silvicultural regeneration in this study cannot be attributed solely to reduced biomass, because more individuals were observed on the unlogged site O1, with a canopy height of only $10 \mathrm{~m}$, than on any of the silvicultural regeneration sites (appendices 1,2). Over one-third of the individuals recorded on this site were crescent honeyeaters (appendix 2) which fed predominantly from inflorescences of Banksia marginata Cav., indicating that the absence of mature populations of certain plant species from silvicultural regeneration contributed heavily to the depauperate nature of their bird assemblages.

Assemblages of birds in older silvicultural regeneration were still distinct from those in old-growth and regrowth forests, even after 26 years. This is consistent with the 
TABLE 2

Mean total numbers of individuals of each bird species and guild recorded from sites in each treatment after 15 surveys

\begin{tabular}{|c|c|c|c|}
\hline \multirow[t]{2}{*}{ Species (code in brackets)* } & \multicolumn{3}{|c|}{ Numbers $^{\dagger}$} \\
\hline & Silviculture & Regrowth & Old-growth \\
\hline spotted pardalote ${ }^{\mathrm{P}}\left(S_{\mathrm{p}} \mathrm{P}\right)$ & $1.40^{\mathrm{a}}(1.45)$ & $5.20^{\mathrm{b}}(2.49)$ & $4.54^{\mathrm{b}}(1.81)$ \\
\hline striated pardalote ${ }^{\mathrm{nP}}(\mathrm{StP})$ & $0.00 \quad(0.00)$ & $0.00 \quad(0.00)$ & $0.15 \quad(0.38)$ \\
\hline black-headed honeyeater ${ }^{\mathrm{np}}(\mathrm{BHH})$ & $4.07^{a}(6.12)$ & $12.80^{\mathrm{b}}(5.59)$ & $8.85^{\mathrm{ab}}(5.79)$ \\
\hline strong-billed honeyeater ${ }^{\mathrm{nP}}(\mathrm{SBH})$ & $5.20 \quad(6.37)$ & $9.20 \quad(8.58)$ & $9.62 \quad(6.04)$ \\
\hline yellow wattlebird $\mathrm{np}(\mathrm{YW})$ & $0.53 \quad(1.55)$ & $0.60 \quad(0.55)$ & $0.31 \quad(0.48)$ \\
\hline black-faced cuckoo-shrike ${ }^{\mathrm{np}}$ (BFC) & $0.00 \quad(0.00)$ & $0.00 \quad(0.00)$ & $0.15 \quad(0.38)$ \\
\hline green rosella ${ }^{\mathrm{nP}}(\mathrm{GR})$ & $7.20^{\mathrm{a}}(5.32)$ & $32.80^{\mathrm{b}}(8.41)$ & $38.15^{b}(14.29)$ \\
\hline sulphur-crested cockatoo ${ }^{\mathrm{np}}$ (SCC) & $0.07 \quad(0.26)$ & $0.00 \quad(0.00)$ & $0.00 \quad(0.00)$ \\
\hline brown goshawk ${ }^{\mathrm{ap}}(\mathrm{BG})$ & $0.27 \quad(0.46)$ & $0.40 \quad(0.89)$ & $0.08 \quad(0.28)$ \\
\hline canopy ${ }^{\mathrm{P}}$ & $18.73^{a}(16.45)$ & $61.00^{b}(11.51)$ & $61.85^{b}(17.92)$ \\
\hline grey fantail "пp (GF) & $2.40^{\mathrm{a}}(2.97)$ & $6.20^{\mathrm{ab}}(2.86)$ & $6.23^{b}(3.24)$ \\
\hline brown thornbill np (BT) & $0.00 \quad(0.00)$ & $0.00 \quad(0.00)$ & $0.08 \quad(0.28)$ \\
\hline Tasmanian thornbill $P(T T)$ & $11.73^{\mathrm{a}}(7.46)$ & $22.00^{\mathrm{ab}}(10.15)$ & $24.23^{b}(12.13)$ \\
\hline scrubtit ${ }^{\mathrm{NP}}(\mathrm{ST})$ & $2.80^{\mathrm{a}}(3.53)$ & $9.40^{*}(6.58)$ & $8.15^{a}(6.74)$ \\
\hline silvereye ${ }^{\mathrm{np}}(S)$ & $8.47^{\mathrm{a}}(5.32)$ & $25.60^{\mathrm{ab}}(19.91)$ & $27.69^{\mathrm{b}}(14.77)$ \\
\hline eastern spinebill ${ }^{\mathrm{np}}(\mathrm{ES})$ & $0.87^{\mathrm{a}}(3.36)$ & $1.40^{2}(1.67)$ & $2.23^{\mathrm{a}}(4.38)$ \\
\hline crescent honeyeater ${ }^{\mathrm{nP}}(\mathrm{CH})$ & $6.93^{\mathrm{a}}(5.76)$ & $25.20^{\mathrm{ab}}(27.01)$ & $25.08^{b}(22.23)$ \\
\hline New Holland honeyeater ${ }^{\mathrm{np}}(\mathrm{NHH})$ & $0.00 \quad(0.00)$ & $0.00 \quad(0.00)$ & $0.08 \quad(0.28)$ \\
\hline yellow-throated honeyeater ${ }^{\mathrm{nP}}$ (YTH) & $2.07^{a}(2.43)$ & $13.20^{\mathrm{b}}(6.26)$ & $10.69^{\mathrm{b}}(3.99)$ \\
\hline olive/golden whistlet $\mathrm{P}(\mathrm{W})$ & $2.93^{\mathrm{a}}(2.66)$ & $6.20^{\mathrm{b}}(1.30)$ & $8.23^{\mathrm{b}}(2.52)$ \\
\hline grey shrike-thrush ${ }^{\mathrm{P}}$ (GST) & $7.13^{2}(5.88)$ & $19.00^{\mathrm{b}}(6.75)$ & $17.77^{\mathrm{b}}(4.92)$ \\
\hline yellow-tailed black cockatoo ${ }^{\mathrm{nP}}(\mathrm{YBC})$ & $0.73 \quad(1.16)$ & $2.40 \quad(2.61)$ & $1.69(1.89)$ \\
\hline mid-layer ${ }^{P}$ & $46.07^{\mathrm{a}}(28.84)$ & $130.60^{\mathrm{b}}(48.43)$ & $132.15^{b}(25.23)$ \\
\hline beautiful firetail np (FF) & $0.00(0.00)$ & $0.20 \quad(0.45)$ & $0.31 \quad(0.63)$ \\
\hline flame robin ${ }^{\text {np }}(F R)$ & $0.33(0.82)$ & $0.40 \quad(0.89)$ & $0.31 \quad(1.11)$ \\
\hline pink robin ${ }^{P}(P R)$ & $3.53^{\mathrm{a}}(3.09)$ & $8.80^{\mathrm{a}}(3.27)$ & $8.62^{\mathrm{a}}(5.53)$ \\
\hline scarlet robin np (SR) & $0.47 \quad(1.81)$ & $0.00 \quad(0.00)$ & $0.15 \quad(0.38)$ \\
\hline dusky robin ${ }^{\mathrm{np}}(\mathrm{DR})$ & $1.67(6.18)$ & $0.00 \quad(0.00)$ & $0.23(0.83)$ \\
\hline superb fairy-wren ${ }^{\mathrm{np}}$ (SFW) & $5.20 \quad(5.61)$ & $2.80 \quad(5.72)$ & $4.23(5.61)$ \\
\hline Tasmanian scrubwren ${ }^{\mathrm{P}}(\mathrm{SW})$ & $4.13^{\mathrm{a}}(2.45)$ & $15.80^{\mathrm{b}}(5.54)$ & $17.00^{b}(4.32)$ \\
\hline Bassian thrush ${ }^{\mathrm{nP}}(\mathrm{T})$ & $0.27 \quad(0.59)$ & $1.40 \quad(1.67)$ & $0.54 \quad(0.78)$ \\
\hline superb lyrebird ${ }^{\mathrm{nP}}(\mathrm{L})$ & $0.20 \quad(0.56)$ & $0.80 \quad(1.30)$ & $0.62(0.65)$ \\
\hline grey butcherbird ${ }^{\mathrm{np}}(\mathrm{GB})$ & $0.07 \quad(0.26)$ & $0.00 \quad(0.00)$ & $0.00 \quad(0.00)$ \\
\hline black currawong ${ }^{\text {np }}(\mathrm{BC})$ & $8.60(15.01)$ & $24.20(37.59)$ & $25.08(44.06)$ \\
\hline forest raven ${ }^{\mathrm{np}}(\mathrm{R})$ & $1.33(2.29)$ & $0.80 \quad(0.84)$ & $1.31(1.60)$ \\
\hline wedge-tailed eagle ${ }^{\mathrm{np}}$ (WTE) & $0.00 \quad(0.00)$ & $0.00 \quad(0.00)$ & $0.23(0.60)$ \\
\hline ground ${ }^{n p}$ & $25.80^{\mathrm{a}}(18.00)$ & $55.20^{\mathrm{ab}}(34.51)$ & $58.62^{b}(42.72)$ \\
\hline
\end{tabular}

${ }^{*} \mathrm{np}=$ non-parametric tests, i.e. Kruskal-Wallis Test followed by pairwise comparisons using Dunn's Method. $\mathrm{p}=$ parametric tests, i.e. 1-way ANOVA followed by pairwise comparisons using Student-Newman-Keuls Test.

${ }^{\dagger}$ Standard deviations are given in brackets. For birds with significant differences in abundances across the three treatments, significant pairwise differences $(p<0.05)$ are denoted by the superscripts a and $b$.

numbers of species and individuals in 7-27-year-old regeneration after clearfelling being lower than in mature forest on ridges in Gippsland (Loyn 1980). Similarly, fewer species were found in 10-15-year-old regeneration after logging and burning, (which left only five trees per hectare) than in mature forest on ridges in southeastern NSW (Smith 1985a, b). This was in spite of recolonisation of clearfelled areas by forest-inhabiting birds as the silvicultural regrowth aged, as occurred in other regrowth forests following logging (e.g. Green 1977, Coulson \& Coulson 1980, Loyn 1980, Smith 1984, 1985b).

\section{Impacts of Selective Logging and Wildfire}

Selective logging 25 years ago followed by wildfire 21 years ago, or wildfire 55 years ago in unlogged forests, did not have significant impacts on bird assemblages. In accord with the present study, similar numbers of species were found in regeneration after selective logging 10-15 years ago and in mature forest in gullies in southeastern NSW (Smith 1985a, b). Smith (1985a) found that a large proportion of species recorded in regrowth spent most of their time in retained trees, and proposed that the number of birds 
TABLE 3

Mean total numbers of individuals of each bird species and guild recorded from sites in each treatment after 15 surveys

\begin{tabular}{|c|c|c|c|}
\hline \multirow[t]{2}{*}{ Species* } & \multicolumn{3}{|c|}{ Numbers $^{\dagger}$} \\
\hline & Silviculture $^{\ddagger}$ & Regrowth & Old-growth \\
\hline spotted pardalote ${ }^{p}$ & $1.40^{\mathrm{a}}(1.58)$ & $5.20^{\mathrm{b}}(2.49)$ & $4.54^{\mathrm{b}}(1.81)$ \\
\hline black-headed honeyeater ${ }^{P}$ & $6.10 \quad(6.67)$ & $12.80 \quad(5.59)$ & $8.85 \quad(5.79)$ \\
\hline green rosella ${ }^{p}$ & $9.60^{a}(4.55)$ & $32.80^{\mathrm{b}}(8.41)$ & $38.15^{\mathrm{b}}(14.29)$ \\
\hline canopy $^{p}$ & $26.20^{\mathrm{a}}(15.06)$ & $61.00^{b}(11.51)$ & $61.85^{b}(17.92)$ \\
\hline grey fantail ${ }^{p}$ & $3.60 \quad(2.99)$ & $6.20 \quad(2.86)$ & $6.23 \quad(3.24)$ \\
\hline Tasmanian thornbill ${ }^{p}$ & $15.0 \quad(5.94)$ & $22.00(10.15)$ & $24.23(12.13)$ \\
\hline silvereye ${ }^{\mathrm{nP}}$ & $11.00^{\mathrm{a}}(2.30)$ & $25.60^{\mathrm{ab}}(19.91)$ & $27.69^{\mathrm{b}}(14.77)$ \\
\hline crescent honeyeater ${ }^{\mathrm{nP}}$ & $9.20 \quad(5.80)$ & $25.20(27.01)$ & $25.08(22.23)$ \\
\hline yellow-throated honeyeater ${ }^{\mathrm{np}}$ & $3.10^{\mathrm{a}}(2.38)$ & $13.20^{\mathrm{b}}(6.26)$ & $10.69^{b}(3.99)$ \\
\hline olive/golden whistler ${ }^{p}$ & $4.40^{\mathrm{a}}(1.96)$ & $6.20^{\mathrm{ab}}(1.30)$ & $8.23^{b}(2.52)$ \\
\hline grey shrike-thrush P & $10.40^{\mathrm{a}}(4.17)$ & $19.00^{\mathrm{b}}(6.75)$ & $17.77^{\mathrm{b}}(4.92)$ \\
\hline mid-layer ${ }^{\mathrm{p}}$ & $63.30^{2}(15.61)$ & $130.60^{\mathrm{b}}(48.43)$ & $132.15^{\mathrm{b}}(25.23)$ \\
\hline Tasmanian scrubwren ${ }^{p}$ & $5.30^{2}(2.00)$ & $15.80^{\mathrm{b}}(5.54)$ & $17.00^{6} \quad(4.32)$ \\
\hline ground ${ }^{\mathrm{np}}$ & $25.20^{a}(10.71)$ & $55.20^{\mathrm{ab}}(34.51)$ & $58.62^{b}(42.72)$ \\
\hline
\end{tabular}

${ }^{*} \mathrm{np}=$ non-parametric tests, i.e. Kruskal-Wallis Test followed by pairwise comparisons using Dunn's Method. $\mathrm{p}=$ parametric tests, i.e. 1-way ANOVA followed by pairwise comparisons using Student-Newman-Keuls Test.

Ttandard deviations are given in brackets. For birds with significant differences in abundances across the three treatments, significant pairwise differences $(\mathrm{p}<0.05)$ are denoted by the superscripts $a$ and $b$.

$¥$ excluding silvicultural regrowth less than nine years old.

TABLE 4

Species of birds less abundant in silvicultural regeneration than old-growth or regrowth forests in Warra, and other studies*

\begin{tabular}{ll}
\hline Species & Studies \\
\hline pink robin & 1 \\
Tasmanian scrubwren & 78 \\
scrubtit & 1 \\
Tasmanian thornbill & 7 \\
golden whistler & 179 \\
grey fantail & 135789 \\
spotted pardalote & 12345678 \\
crescent honeyeater & 14789 \\
black-headed honeyeater & 789 \\
strong-billed honeyeater & 789 \\
yellow-throated honeyeater & 78 \\
green rosella & 78 \\
grey shrike-thrush & 2379 \\
\hline
\end{tabular}

* Studies which have found similar results elsewhere: codes $1=$ Green 1977; 2 = Loyn 1980;3 = Kavanagh et al. 1985; 4 = Loyn 1985; 5 = Recher et al. 1985; 6 = Smith 1985a; 7 = Dickinson $e t$ al. 1986; 8 = Taylor \& Haseler 1995; 9 = Taylor et al. 1997.

inhabiting regrowth would have been greatly reduced if trees had not been retained. This opinion is supported by the absence of an impact on the number of species in gullies, where, on average, 12 trees per hectare were retained, while logging on ridges, which left an average of only five trees per hectare, significantly reduced the number of species (Smith 1985a, b). Similarly, in southeastern Tasmania, Taylor et al.
(1997) found that more bird species occurred in areas of young regrowth where $20-80$-year-old trees were retained than in completely clearfelled areas. Hence, the low numbers of birds found during the present study in regrowth following clearfelling compared with selective logging may be due to the almost complete absence of older trees in the former. Another possible reason for the severe impact on birds of clearfelling compared with selective logging is the more intense fires associated with regeneration after clearfelling.

However, the similarity found in this study between bird assemblages in selectively logged and old-growth forests contrasts with the lower numbers of individuals and species found in Gippsland gully forests selectively logged 15 years earlier compared with those unlogged (Loyn 1980). In the Gippsland study, regrowth forests 40 years or more after selective logging and/or wildfire still had less species and individuals than mature forest. The absence of differences in bird communities between regrowth and old-growth forests in the present study may be due to many of the oldgrowth forests also being burnt 55 years ago, when the regrowth forests were burnt.

\section{Impacts of Clearfelling on Particular Species}

Numerous species adversely affected by clearfelling in this study have exhibited similar responses elsewhere (table 4). However, most other studies where silvereyes occurred did not find differences in their abundances between mature forests and silvicultural regeneration (e.g. Green 1977, Kavanagh et al. 1985, Loyn 1985, Taylor et al. 1997). Indeed, one southeastern NSW study (Smith 1985a) found silvereyes were more abundant in regrowth, where between five and 12 trees had been retained per hectare of logging coupe, than in mature forest. 
Uncommon species recorded from old-growth and/or regrowth forests but not from silvicultural regeneration in the present study also exhibited similar patterns in some other situations. Striated pardalotes were much less common in silvicultural regeneration than in mature forest in Tasmania (Dickinson et al. 1986, Taylor \& Haseler 1995, Taylor et al. 1997) and in Gippsland in Victoria (Loyn 1980, 1985). The beautiful firetail, black-faced cuckooshrike and wedge-tailed eagle were also observed in unlogged forest but not in silvicultural regeneration by Green (1977), but in both silvicultural regeneration and mature forest studied by Taylor et al. (1997). New Holland honeyeaters were absent from silvicultural regeneration while present in mature forest in one study (Taylor et al. 1997), but they exhibited no significant differences in abundance between 17-year-old silvicultural regeneration and mature forest in another (Taylor \& Haseler 1995). Similarly, brown thornbills were sometimes adversely affected by silvicultural practices (Dickinson et al. 1986, Taylor et al. 1997) and sometimes not (Green 1977, Taylor \& Haseler 1995).

In spite of the generally deleterious impacts on birds, clearfelling and burning did create habitat for three robin species which foraged in open areas. The favouring of recently logged areas by species which feed on open ground has also been recorded in Victoria (Loyn 1980) and in parts of Tasmania other than those studied here (Green 1977, Dickinson et al. 1986, Taylor \& Haseler 1995, Taylor et al. 1997). However, Coulson \& Coulson (1980) regarded this as inadequate compensation for the loss of forestdwelling birds, because species favouring open areas have already benefited from land clearance for agriculture. Furthermore, this provision of habitat for robins was shortlived, as they were virtually absent from silvicultural regeneration four or more years after burning. Loyn (1980) also found that scarlet and flame robins did not inhabit 6-10-year-old regrowth in Gippsland, and Kavanagh et al. (1985) noted that birds typical of open country, which colonised recently logged areas in southeastern NSW, disappeared within two years.

The tendency for dusky and flame robins to frequent areas subjected to burning was also apparent in drier forests in southeastern Tasmania. Both species were more common on burnt logging coupes than on those where logging slash remained (Dickinson et al. 1986) and were more abundant after a high intensity fire in woodland than after either a low intensity fire or no fire (Hingston \& Black 1998). However, Coulson \& Coulson (1980) recorded these two species most frequently in mature dry sclerophyll forest in Tasmania, although they were also present in a recently clearfelled and burnt coupe as well as in six-year-old silvicultural regeneration. Intermediate results obtained by Taylor et al. (1997), showed that, although the dusky robin was more common in silvicultural regeneration 0-6 years old than in either older silvicultural regeneration or mature dry sclerophyll forest, flame robins were equally abundant in young silvicultural regeneration and mature forest but less common in older silvicultural regeneration.

The apparent preference of the scarlet robin for the recently burnt coupe which was found during this study contrasts with previous studies in other parts of Tasmania. This species was regularly observed in mature dry sclerophyll forest, but it was never recorded from recently clearfelled coupes or young regrowth during the studies of Green (1977) or Coulson \& Coulson (1980). It was also more common in mature dry sclerophyll forest than in recently logged areas investigated by Dickinson et al. (1986) and Taylor \& Haseler (1995). This difference is most likely to be due to the species inhabiting mature dry sclerophyll forests but not wet sclerophyll forests. This is supported by its absence from wet sclerophyll forest (Green 1977), and the only old-growth forests where it was recorded during the present study being at the drier end of the scale.

The only common species with similar abundances in silvicultural regeneration and old-growth forests was the superb fairy-wren. Other Tasmanian studies have also found this species to be resilient to silvicultural practices (e.g. Green 1977, Dickinson et al. 1986). Furthermore, in southeastern NSW this species was more common in areas logged without regeneration burning than in unlogged areas (Kavanagh et al. 1985). However, although Taylor \& Haseler (1995) found numbers of this species in 17-yearold silvicultural regeneration to be similar to those in mature forest, abundances were significantly lower in threeyear-old silvicultural regeneration, suggesting that intense regeneration burns may be disadvantageous to the species. In contrast, Taylor et al. (1997) found similar numbers in silvicultural regeneration aged $0-6$ years and mature forest, but significantly lower abundances in 6-12-year-old silvicultural regeneration. In the latter case, the low numbers in older silvicultural regeneration may have been the result of only recording birds which were seen together with the dense foliage at eye level (Taylor et al. 1997).

\section{CONCLUSIONS}

The difference between bird populations in silvicultural regeneration and in other treatments in this study may be even greater than is suggested by the results, due to birds being more easily detected in logged areas (Kavanagh et al. 1985, Taylor \& Haseler 1995, Taylor et al. 1997). The deleterious impact of silvicultural practices on bird populations may also have been underestimated because of the assumption of independence between treatments, which is clearly invalid, because birds are highly vagile. Bird populations in unlogged areas in this study may also have been reduced by logging in nearby areas, as Kavanagh et al. (1985) found that some species were less abundant in small unlogged areas than large unlogged areas. Similarly, bird populations in silvicultural regeneration may have been enhanced by the presence of mature forest nearby, as most birds observed in young regrowth by Smith (1984) were transients from nearby mature forest. Furthermore, the number of species in another area of silvicultural regeneration declined after a contiguous area of mature forest was logged (Coulson \& Coulson 1980).

This study has demonstrated that bird populations are lower in silvicultural regeneration under 30 years old than in old-growth forests. Hence, forests logged for pulpwood on a rotation length of approximately 30 years are likely to have reduced bird populations throughout. For areas logged on longer rotations for sawlogs, the degree of impact will depend on whether bird populations recover in silvicultural regeneration of more than 30 years of age. However, in Gippsland, fewer birds were found in regrowth aged between 40 and 100 years than in regrowth aged 10-30 years (Loyn 1980). Even if, in southern Tasmania, bird assemblages in older silvicultural regeneration are similar to those in unlogged forests, the overall numbers of birds in the area can still be expected to be dramatically reduced. If forests 
are logged on a $60-80$ year rotation, at any given time between one-third and one-half of the production area will carry silvicultural regeneration of equivalent age to that studied here and, hence, significantly fewer birds.

Further research should focus on whether species can survive in silvicultural regeneration without nearby mature forest, and whether reserved areas within production forests will be sufficient to maintain viable populations. Studies are also required at other times of the year to fully determine the response of birds to forestry operations, as numerous species are summer migrants to Tasmania, and many other species migrate locally or are nomadic. In the longer term, the questions of how long it takes for bird populations to recover fully from clearfelling and burning of their habitat, and whether bird assemblages recover at the same rate in the second cycle of silvicultural regeneration as in the first, need to be addressed. Future studies would benefit from analyses of the detectability of birds in different habitats, by constructing sightability curves or comparing ratios of birds seen to those heard, and by recording the amounts of time individuals spend in each habitat in addition to the numbers of individuals observed.

\section{ACKNOWLEDGEMENTS}

I would like to thank Forestry Tasmania for financing this research and Dr Robert Taylor for initiating it as well as commenting on drafts of this paper.

\section{REFERENCES}

AbBott, I. \& VAN Huerck, P., 1985: Response of bird populations in jarrah and yarri forest in Western Australia following removal of half the canopy of the jarrah forest. Aust. For. 48: 227-234.

BELBIN, L., 1993: USERS GUIDE. PATN PATTERN ANALYSIS PACKAGE. CSIRO Division of Wildlife \& Ecology, Canberra.

COULSON, R.L. \& Coulson, G.M., 1980: THE EFFECTS OF FORESTRY PRACTICES ON BIRD BREEDING IN OPEN FOREST. 1980/4. Centre for Environmental Studies, University of Tasmania, Hobart.

Dickinson, K.J.M., Wall, L.E. \& WILson, R.I., 1986: Birds in a partly clearfelled dry eucalypt forest on dolerite in southeastern Tasmania. Pap. Proc. R. Soc. Tasm. 120: $39-49$

GILMORE, A.M., 1985: The influence of vegetation structure on the density of insectivorous birds. In Keast, A., Recher, H.F., Ford, H. \& Saunders, D. (Eds): BIRDS OF EUCALYPT FORESTS AND WOODLANDS:
ECOLOGY, CONSERVATION, MANAGEMENT. Royal Australasian Ornithologists Union and Surrey Beatty \& Sons, Chipping Norton, NSW: 21-31.

Green, R.H., 1977: The vertebrate fauna of Maggs Mountain, Tasmania. Rec. Q.Vict. Mus. 58: 1-40.

Hingston, A.B. \& BLACK, P.G., 1998: The short-term effects of fire and its intensity on avian abundance in Eucalyptus pulchella woodland. Tasm. Nat. 120: 31-43.

Kavanagh, R.P., Shields, J.M., Recher, H.F. \& Rohan-Jones, W.G., 1985: Bird Populations of a Logged and Unlogged Forest Mosaic at Eden, New South Wales. In Keast, A., Recher, H.F., Ford, H. \& Saunders, D. (Eds): BIRDS OF EUCALYPT FORESTS AND WOODLANDS. ECOLOGY, CONSERVATION, MANAGEMENT. Royal Australasian Ornithologists Union and Surrey Beatty \& Sons, Chipping Norton, NSW: 273-281.

Loyn, R.H., 1980: Bird populations in a mixed eucalypt forest used for production of wood in Gippsland, Victoria. Еmu 80: 145-156.

Loyn, R.H., 1985: Ecology, Distribution, and Density of Birds in Victorian Forests. In Keast, A., Recher, H.F., Ford, H. \& Saunders, D. (Eds): BIRDS OF EUCALYPT FORESTS AND WOODLANDS: ECOLOGY, CONSERVATION, MANAGEMENT. Royal Australasian Ornithologists Union and Surrey Beatty \& Sons, Chipping Norton, NSW: 33-46.

Recher, H.F., Allen, D. \& Gowing, G., 1985: The impact of wildfire on birds in an intensively logged forest. In Keast, A., Recher, H.F., Ford, H. \& Saunders, D. (Eds): BIRDS OF EUCALYPT FORESTS AND WOODLANDS: ECOLOGY, CONSERVATION, MANAGEMENT. Royal Australasian Ornithologists Union and Surrey Beatty \& Sons, Chipping Norton, NSW: 283-290.

Smith, P., 1984: The forest avifauna near Bega, New South Wales I. Differences between forest types. Emu 84: 200210.

SMrTH, P., 1985a: Effects of intensive logging on birds in eucalypt forest near Bega, New South Wales. Emu 85: 15-21.

SmITH, P. 1985b: Woodchip Logging and Birds near Bega, New South Wales. In Keast, A., Recher, H.F., Ford, H. \& Saunders, D. (Eds): BIRDS OF EUCALYPT FORESTS AND WOODLANDS: ECOLOGY, CONSERVATION, $M A N A G E M E N T$. Royal Australasian Ornithologists Union and Surrey Beatty \& Sons, Chipping Norton, NSW: 259-271.

TAYloR, R.J. \& HASELER, M.E., 1995: Effects of partial logging systems on bird assemblages in Tasmania. For. Ecol. Manage. 72: 131-149.

TaYlor, R.J., DuckWorth, P., Johns, T. \& Warren, B., 1997: Succession in bird assemblages over a seven-year period in regrowth dry sclerophyll forest in south-east Tasmania. Ети 97: 220-230.

(accepted 28 March 2000) 
APPENDIX 1

Numbers of each bird species observed during 15 surveys at each silvicultural regeneration site

\begin{tabular}{|c|c|c|c|c|c|c|c|c|c|c|c|c|c|c|c|}
\hline Species* & S1 & S2 & S3 & S4 & S5 & S6 & S7 & S8 & S9 & $\mathrm{S} 10$ & S11 & $S 12$ & $\$ 13$ & S14 & S15 \\
\hline SpP & - & - & 3 & 2 & 2 & 1 & - & - & 1 & 5 & 1 & - & 1 & 3 & 2 \\
\hline $\mathrm{StP}$ & - & - & - & - & - & - & - & - & - & - & - & - & - & - & - \\
\hline $\mathrm{BHH}$ & - & - & - & - & - & - & 1 & 4 & 2 & 21 & - & 10 & 3 & 9 & 11 \\
\hline $\mathrm{SBH}$ & - & - & - & - & - & - & 3 & 14 & - & 20 & 5 & 12 & 8 & 10 & 6 \\
\hline YW & - & - & - & - & - & - & - & 1 & - & - & 6 & - & - & - & 1 \\
\hline $\mathrm{BFC}$ & - & - & - & - & - & - & - & - & - & - & - & - & - & - & - \\
\hline GR & - & - & 7 & 4 & 1 & 7 & 4 & 7 & 12 & 12 & 11 & 6 & 7 & 20 & 10 \\
\hline SCC & - & - & - & - & - & - & - & - & - & - & - & 1 & - & - & - \\
\hline $\mathrm{BG}$ & - & - & - & - & - & 1 & 1 & 1 & 1 & - & - & - & - & - & - \\
\hline GF & - & - & - & - & - & - & - & 5 & 1 & 5 & 1 & 3 & 7 & 6 & 8 \\
\hline BT & - & - & - & - & - & - & - & - & - & - & - & - & - & - & - \\
\hline $\mathrm{TT}$ & - & - & 14 & 4 & 8 & 8 & 19 & 19 & 6 & 20 & 18 & 21 & 20 & 10 & 9 \\
\hline ST & - & - & - & 1 & - & 1 & 1 & 1 & 4 & 5 & 2 & 9 & 12 & 3 & 3 \\
\hline$S$ & - & - & 2 & - & 11 & 13 & 10 & 12 & 12 & 10 & 13 & 12 & 14 & 12 & 6 \\
\hline ES & - & - & - & - & - & - & - & - & - & - & - & - & - & - & 13 \\
\hline $\mathrm{CH}$ & - & 3 & 4 & 2 & 3 & 4 & 5 & 17 & 6 & 16 & 6 & 7 & 4 & 19 & 8 \\
\hline $\mathrm{NHH}$ & - & - & - & - & - & - & - & - & - & - & - & - & - & - & - \\
\hline YTH & - & - & - & - & - & 1 & 1 & 7 & 2 & 6 & 1 & 1 & 2 & 5 & 5 \\
\hline $\mathrm{W}$ & - & - & - & - & - & 4 & 6 & 3 & 1 & 8 & 4 & 3 & 4 & 5 & 6 \\
\hline GST & - & - & 3 & - & - & 1 & 15 & 13 & 12 & 8 & 9 & 8 & 15 & 12 & 11 \\
\hline YBC & - & - & - & - & 3 & - & - & - & 1 & 2 & 3 & 2 & - & - & - \\
\hline FF & - & - & - & - & - & - & - & - & - & - & - & - & - & - & - \\
\hline FR & 3 & - & - & - & - & - & 1 & 1 & - & - & - & - & - & - & - \\
\hline PR & - & - & 1 & 2 & 3 & 2 & 2 & 1 & 2 & 7 & 9 & 5 & 3 & 9 & 7 \\
\hline SR & 7 & - & - & - & - & - & - & - & - & - & - & - & - & - & - \\
\hline DR & 24 & 1 & - & - & - & - & - & - & - & - & - & - & - & - & - \\
\hline SFW & 3 & 17 & 1 & 2 & 4 & 2 & 16 & 6 & 2 & 9 & 11 & - & - & 5 & - \\
\hline SW & 1 & 2 & 3 & 3 & - & 6 & 2 & 9 & 3 & 5 & 7 & 6 & 6 & 4 & 5 \\
\hline $\mathrm{T}$ & - & - & - & - & - & 2 & - & - & - & - & - & - & - & 1 & 1 \\
\hline $\mathrm{L}$ & - & - & - & - & - & - & 1 & - & - & - & - & - & - & 2 & - \\
\hline GB & - & - & - & - & - & - & - & 1 & - & - & - & - & - & - & - \\
\hline $\mathrm{BC}$ & - & 50 & - & - & - & 1 & 4 & 12 & 38 & 2 & - & 3 & 6 & 10 & 3 \\
\hline $\mathrm{R}$ & 8 & - & - & - & - & - & - & - & 3 & 1 & - & 3 & - & 4 & 1 \\
\hline WTE & - & - & - & - & - & - & - & - & - & - & - & - & - & - & - \\
\hline Total birds & 46 & 73 & 38 & 20 & 35 & 54 & 92 & 134 & 109 & 162 & 107 & 112 & 112 & 149 & 116 \\
\hline Total spp. & 6 & 5 & 9 & 8 & 8 & 15 & 17 & 19 & 18 & 18 & 16 & 17 & 15 & 19 & 19 \\
\hline
\end{tabular}

* Species codes are given in table 2. 
APPENDIX 2

Numbers of each bird species observed during 15 surveys at each non-silvicultural regeneration site

\begin{tabular}{|c|c|c|c|c|c|c|c|c|c|c|c|c|c|c|c|c|c|c|}
\hline Species* & $\mathrm{R} 1$ & $\mathrm{R} 2$ & $\mathrm{R} 3$ & $\mathrm{R} 4$ & $\mathrm{R} 5$ & $\mathrm{O} 1$ & $\mathrm{O} 2$ & $\mathrm{O} 3$ & O4 & 05 & O6 & 07 & 08 & $\mathrm{O} 9$ & $\mathrm{O} 10$ & $\mathrm{O} 11$ & $\mathrm{O} 12$ & 013 \\
\hline$S_{p P}$ & 3 & 9 & 5 & 3 & 6 & 3 & 7 & 5 & 3 & 6 & 4 & 6 & 4 & 3 & 5 & 8 & 3 & 2 \\
\hline StP & - & - & - & - & - & - & - & - & - & - & - & - & - & 1 & 1 & - & - & - \\
\hline $\mathrm{BHH}$ & 5 & 15 & 17 & 18 & 9 & 3 & 15 & 7 & 4 & 5 & 11 & 20 & 13 & 16 & 6 & 7 & 8 & - \\
\hline SBH & - & 21 & 15 & 6 & 4 & 3 & 18 & 7 & 1 & 4 & 16 & 9 & 9 & 12 & 13 & 12 & 19 & 2 \\
\hline YW & - & 1 & 1 & 1 & - & 1 & 1 & - & - & - & - & - & 1 & - & - & 1 & - & - \\
\hline $\mathrm{BFC}$ & - & - & - & - & - & - & 1 & - & - & - & 1 & - & - & - & - & - & - & - \\
\hline GR & 34 & 19 & 35 & 34 & 42 & 13 & 30 & 31 & 29 & 30 & 33 & 42 & 39 & 47 & 36 & 43 & 49 & 74 \\
\hline SCC & - & - & - & - & - & - & - & - & - & - & - & - & - & - & - & - & - & - \\
\hline $\mathrm{BG}$ & - & - & - & 2 & - & - & - & - & - & - & - & - & 1 & - & - & - & - & - \\
\hline GF & 3 & 6 & 8 & 10 & 4 & 5 & 7 & 1 & 2 & 11 & 5 & 10 & 6 & 8 & 3 & 9 & 10 & 4 \\
\hline BT & - & - & - & - & - & - & - & - & 1 & - & - & - & - & - & - & - & - & - \\
\hline $\mathrm{TT}$ & 39 & 18 & 13 & 23 & 17 & 22 & 18 & 6 & 29 & 47 & 16 & 42 & 40 & 26 & 19 & 17 & 14 & 19 \\
\hline ST & 3 & 6 & 7 & 20 & 11 & 2 & - & - & 7 & 13 & 6 & 2 & 7 & 7 & 8 & 16 & 17 & 21 \\
\hline$S$ & 46 & 47 & 20 & 11 & 4 & 13 & 52 & 32 & 28 & 43 & 34 & 21 & 12 & 8 & 19 & 31 & 15 & 52 \\
\hline ES & 2 & 4 & - & - & 1 & - & 1 & 2 & - & - & 16 & - & - & 5 & 2 & 2 & - & 1 \\
\hline $\mathrm{CH}$ & 72 & 23 & 13 & 14 & 4 & 69 & 58 & 58 & 7 & 16 & 28 & 22 & 25 & 4 & 7 & 8 & 11 & 13 \\
\hline $\mathrm{NHH}$ & - & - & - & - & - & - & - & - & - & - & - & - & 1 & - & - & - & - & - \\
\hline YТН & 12 & 20 & 18 & 12 & 4 & 9 & 16 & 9 & 12 & 14 & 8 & 10 & 11 & 15 & 12 & 15 & 6 & 2 \\
\hline W & 5 & 5 & 8 & 7 & 6 & 8 & 10 & 4 & 7 & 7 & 10 & 12 & 6 & 8 & 9 & 7 & 6 & 13 \\
\hline GST & 13 & 28 & 17 & 24 & 13 & 20 & 16 & 7 & 23 & 19 & 17 & 21 & 24 & 17 & 18 & 20 & 20 & 9 \\
\hline YBC & - & - & 2 & 6 & 4 & 5 & - & 3 & 2 & - & - & 3 & - & 4 & 1 & 4 & - & - \\
\hline $\mathrm{FF}$ & 1 & - & - & - & - & 2 & 1 & - & - & 1 & - & - & - & - & - & - & - & - \\
\hline FR & 2 & - & - & - & - & - & - & 4 & - & - & - & - & - & - & - & - & - & - \\
\hline PR & 5 & 6 & 9 & 12 & 12 & - & 9 & 5 & 11 & 7 & 11 & 2 & 9 & 5 & 8 & 14 & 22 & 9 \\
\hline SR & - & - & - & - & - & - & 1 & - & 1 & - & - & - & - & - & - & - & - & - \\
\hline DR & - & - & - & - & - & - & - & - & - & - & - & 3 & - & - & - & - & - & - \\
\hline SFW & 13 & - & 1 & - & - & - & 6 & 2 & 10 & 20 & 3 & 3 & 6 & - & - & - & 1 & 4 \\
\hline SW & 7 & 15 & 16 & 21 & 20 & 10 & 18 & 10 & 19 & 23 & 15 & 20 & 21 & 19 & 20 & 14 & 20 & 12 \\
\hline $\mathrm{T}$ & - & - & 1 & 2 & 4 & - & - & - & - & 2 & 2 & 1 & - & - & - & 1 & 1 & - \\
\hline $\mathrm{L}$ & - & 3 & - & 1 & - & 1 & - & - & - & - & - & - & 1 & 1 & 1 & 1 & 1 & 2 \\
\hline GB & - & - & - & - & - & - & - & - & - & - & - & - & - & - & - & - & - & - \\
\hline $\mathrm{BC}$ & 2 & 91 & 14 & 8 & 6 & - & 2 & - & 20 & 2 & 5 & 1 & 7 & 67 & 51 & 13 & 4 & 154 \\
\hline $\mathrm{R}$ & - & 1 & - & 1 & 2 & 1 & 3 & - & 3 & 1 & 4 & - & 1 & - & - & 4 & - & - \\
\hline WTE & - & - & - & - & - & 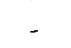 & 1 & - & 2 & - & - & - & - & - & - & - & - & - \\
\hline Total & & * & & & & & & & & & & & & & & & & \\
\hline $\begin{array}{l}\text { birds } \\
\text { Total }\end{array}$ & 267 & 338 & 220 & 236 & 173 & 190 & 291 & 193 & 221 & 271 & 245 & 250 & 244 & 273 & 239 & 247 & 227 & 393 \\
\hline spp. & 18 & 19 & 19 & 21 & 19 & 18 & 22 & 17 & 21 & 19 & 20 & 19 & 21 & 19 & 19 & 21 & 18 & 17 \\
\hline
\end{tabular}

* Species codes are given in table 2. 